NOTED

\section{Awakening from the slumber before too late}

Seventeen Contradictions and the End of Capitalism, by David Harvey. London: Profile Books. 2015, 338pp. ISBN 978-1-78125-16-4

$\mathrm{N}^{\circ}$ OW available in paperback for the first time, American-based scholar of Marxism David Harvey's analysis of the current crisis in capitalism provides an intriguing and thought provoking read.

Harvey's familiarity with Marx is demonstrated throughout the book. He makes it clear, that while thoroughly grounded in the Marxist tradition, his analysis is not meant to be orthodox. The book is accessible to those not entirely familiar with Marx beyond the usual slogans, but he demands attention from his readers as he takes them through a variety of economic concepts.

Nobody would argue with Harvey's basic principle that capitalism is facing yet another crisis, indeed he argues that crises, as the product of the many contradictions inherent in capitalism, are precisely what keep capitalism going.

Unfortunately, as capitalism reels from one crisis to another, attempts to find remedies are all too often solutions to the previous crisis, not the present one, so that solutions are out of kilter with reality.

This means that all too often the landscape created by capitalism remains the same, or else is constantly recreated. As Harvey sadly notes:

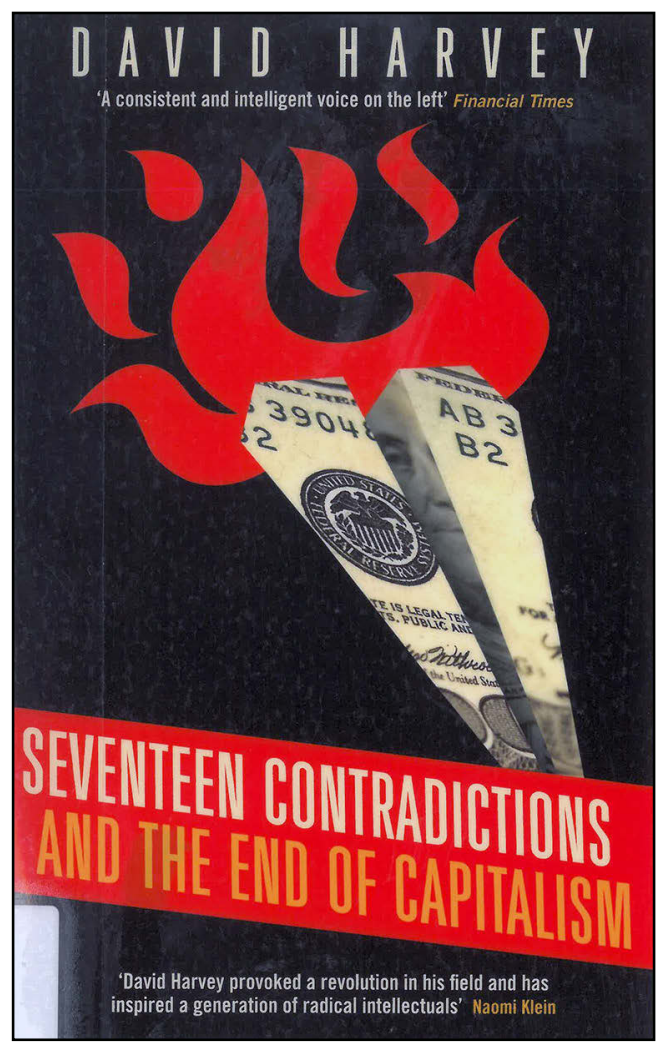

How easy it is to take descriptions of contemporary labour conditions in, for example, the electronics factories of Shenzen, the clothing factories of Bangladesh or the sweatshops of Los Angeles and insert them into Marx's classic chapter on 'the working day' in Capital and not notice the difference. How shockingly easy it is to take the living conditions of the working classes, the marginalised and the unemployed in Lisbon, Sao Paulo and Jakarta and put them next to Engel's classic 1844 description of The Condition of the Working Class in England and find little substantive difference. (p. 292)

Harvey places his hope in people and trusts that they will wake from their sleep before it is too late. He counsels against many of 
what he sees as the follies of modern leftist thought, especially its concentration on identity politics at the expense of class action and analysis, and urges his readers to recognise the existence of potential allies among the many expressions of the secular and religious humanist tradition.

He ends with a suggestion for 17 points of discussion to keep the dialogue alive and to concentrate people's minds on what may be to many, unimaginable, solutions so that a way may be found to implement them.Dr Philip Cass is PJR reviews editor.

\section{Disengagement and idiocy}

American Democracy, by Andrew Perrin. Cambridge: Polity Press. 2014, 228pp. ISBN 978-0-7456622-32-9

$\mathrm{P}$ ERRIN'S study of American democracy is as exhausting as it is exhaustive in its explanation of how it is supposed to work. It begins by stating what has become a commonplace fear in many democracies, that people have become cynical and distrusting of the democratic system and that apathy and political disengagement are widespread. Only multi-millionaires backed by capitalist corporations with the deepest pockets can afford to run for office in the United States and nobody in power seems to be in any hurry to do anything about it.

American democracy was a first attempt to fashion a form of representative government that has been rendered unfit for purpose in recent decades by the greed, corruption and stupidity of elected officials and the disengagement of large sections of the public.

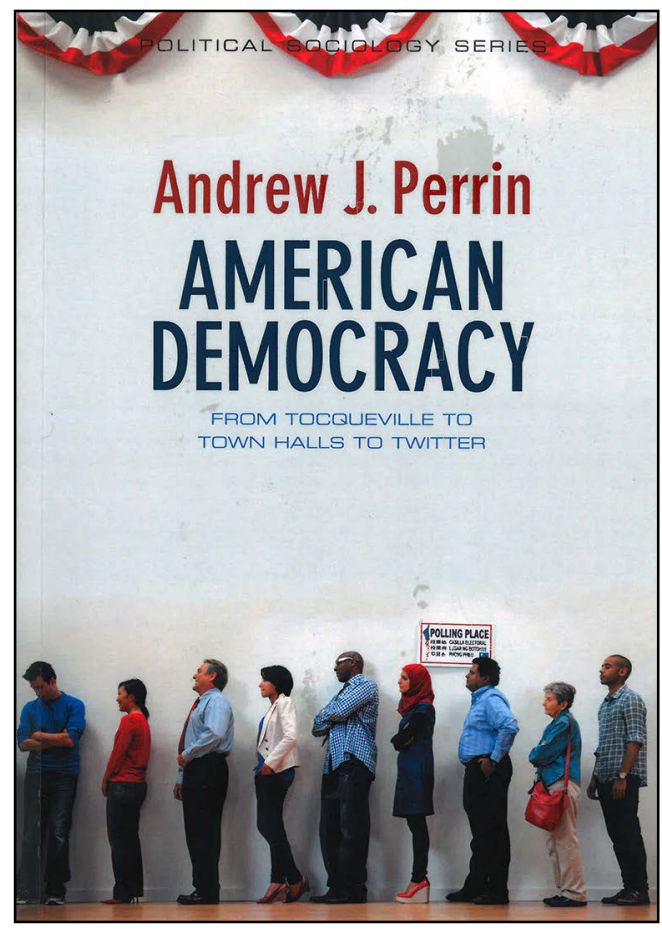

To outsiders it often seems that the American parties are simply two groups of capitalists, with the Democrats being only left of centre by the merest whisker and the Republicans apparently consisting of raving lunatics. It is difficult to believe that any of the 24 percent of Republicans who Perrin claims think that Obama is the Antichrist should be allowed anywhere near a ballot box, let alone a gun.

Such extremes of disengagement and idiocy are dangerous precisely because they silence the voices of those who need to be heard the most. (Perrin says that African Americans would probably be far better off under a Parliamentary system). Such disengagement from the democratic process is dangerous, he argues, for the people only become a political force when they become 